\title{
PENGARUH PROMOSI TERHADAP PENJUALAN PRODUK PUPUK ORGANIK HEMAL BIO DI PT. HEMAL AGRINUSA JAKARTA
}

\author{
Junaidi Hendro \\ PT Hemal Agrinusa \\ agrinusamesin@gmail.com
}

\begin{abstract}
The purpose of this study is to determine and analyze the influence of promotion on the sale of Organic Fertilizer Products Hemal Bio. The method used is quantitative method. The results showed that the increase in sales means that the promotion of the company has an influence on product sales. Evident from result of regression variable of Promotion have value 0,711 . This is confirmed by the test with a tcount of 5,462 and ttable (95\%: 30-2) of 2,048, with significance level or Pvalue $=$ 0,000 meaning less than the significance level $\alpha=0.05$. From these results then the testing criteria are thitung $>$ ttable and Pvalue $<\alpha$ means $\mathrm{H} 0$ rejected and $\mathrm{H} 1$ accepted. In conclusion Promotion has a positive and significant effect on Sales of Hemal Bio Fertilizer by PT. HemalAgronusa, Jakarta.
\end{abstract}

Keywords: Promotion and Sales

\section{PENDAHULUAN}

\subsection{Latar Belakang Masalah}

Masyarakat Indonesia saat ini sudah mulai menyadari bahwa produk-produk pangan yang selama ini mereka konsumsi sangat membahayakan kesehatan tubuh mereka karena bahan-bahan kimia. Untuk mengatasi hal itu maka saat ini banyak orang sudah mulai beralih mengkonsumsi bahan makanan yang bersifat organik, misalnya sayur organik dan padi organik (Winarno, 2002). Dalam mendukung pemenuhan kebutuhan bahan makanan yang bersifat organik, maka petani saat ini mulai beralih ke pertanian organik yang salah satunya dengan cara menggunakan pupuk organik yang di produksi oleh kelompok-kelompok tani yang terbentuk oleh bantuan pemerintah (Leiwakabessy dan Sutandi, 2004).

Melihat peluang tersebut banyak kalangan (pengusaha, produsen, pedagang) yang cepat beralih ke produk organik dengan memanfaatkan berbagai limbah untuk pembuatan pupuk organik. Hal tersebut menjadi persaingan dalam memasarkan pupuk organik semakin ketat.Untuk mengatasi ketatnya persaingan dalam pemasaran produk pupuk organik, maka salah satu upaya yang dilakukan oleh perusahaan adalah dengan menerapkan strategi promosi, di mana dalam penerapan strategi tersebut perusahaan berusaha untuk melakukan promosi yang mampu bersaing, sehingga peningkatan penjualan pupuk organik terus meningkat. 
PT. Hemal Agrinusa Jakarta merupakan salah satu perusahaan yang bergerak dalam menyalurkan dan memasarkan pupuk organik yang terletak di Jakarta agar dapat memenuhi kebutuhan konsumen dan sekaligus masalah keuntungan bagi produsen.

Menurut Kotler (2002), pemasaran merupakan hal yang paling penting dilaksanakan oleh perusahaan dalam usahanya menciptakan pasar untuk memperoleh kesempatan mendapatkan laba yang optimal dan menjaga kelangsungan hidup suatu usaha. Salah satu usaha dalam bidang apapun memerlukan dukungan konsep pemasaran berupa bauran pemasaran (marketing mix) yakni mencakup produk, harga, promosi dan distribusi. Untuk mencapai tujuan pemasaran, maka keempat unsur tersebut harus saling mendukung antara satu dengan yang lainnya. Tidak bisa hanya satu komponen saja yang diprioritaskan, sebab apabila perusahaan ingin memenuhi kebutuhan secara memuaskan maka harus didukung oleh keempat unsur diatas.

Promosi merupakan salah satu diantara beberapa kegiatan pemasaran yang mempunyai peranan penting karena merupakan penunjang langsung terhadap kegiatan perusahaan untuk menginformasikan, memberitahukan, membujuk, dan memengaruhi konsumen dalam memilih atau membeli suatu produk yang ditawarkan oleh perusahaan, dan juga terhadap volume penjualan untuk memperoleh laba yang optimal dari hasil penjualan yang maksimal.

Dalam kaitannya dengan uraian tersebut di atas, maka sangat menarik untuk meneliti permasalahan yang ada dalam perusahaan mengenai pengaruh promosi terhadap penjualan, khususnya pupuk organik.

\subsection{Perumusan Masalah}

Adapun rumusan masalah yang dapat penulis sumpulkan adalah: Bagaimana pengaruh promosi terhadap penjualan produk pupuk organik Hemal Bio di PT. Hemal Agrinusa Jakarta?

\subsection{Tujuan Penelitian}

1. Untuk mengetahui pengaruh promosi terhadap penjualan produk pupuk organik Hemal Bio di PT. Hemal Agrinusa Jakarta?

2. Untuk menganalisis pengaruh promosi terhadap penjualan produk pupuk organik Hemal Bio di PT. Hemal Agrinusa Jakarta?

\subsection{Kerangka Berpikir}

Kegiatan promosi yang dilakukan perusahaan merupakan gabungan dari unsur bauran promosi yang terdiri dari advertising, sales promotion, Personal selling, dan publisitas. Sedangan volume penjualan terdiri atas konsumen. yang mempengaruhi penjualan melalui daya beli dan selera pasar.

Berdasarkan uraian diatas, dapat digambarkan sebagai berikut:

\begin{tabular}{|l|l|}
\hline Promosi (X): & \\
1. Advertising & \\
2. Sales Promotion & \\
3. Personal Selling & Penjualan (Y) \\
4. Publisitas & \\
\hline
\end{tabular}




\subsection{Hipotesis Penelitian}

Sesuai dengan latar belakang dan masalah pokok yang dikemukakan, maka hipotesis statistik dalam penelitian ini adalah :

Ho : $r \neq 0$ Terdapat pengaruh antara Promosi dan volume penjualan. Jika promosi makin tinggi maka volume penjualan akan meningkat

Ha : $r=0$ Tidak terdapat pengaruh antara Promosi dan Volume penjualan jika promosi makin tinggi maka volume penjualan akan menurun

\section{Kajian Literatur}

\subsection{Pengertian Promosi}

Pengertian promosi menurut Saladin dan Oesman (2002 : 123) : "Promosi adalah suatu komunikasi informasi penjual dan pembeli yang bertujuan untuk merubah sikap dan tinakah laku pembeli, yang sebelumnya tidak mengenal menjadi mengenal sehingga menjadi pembeli dan mengingat produk tersebut". Sedangkan pengertian promosi menurut Alma (2006 : 179) adalah : "Promosi adalah sejenis komunikasi yang memberi penjelasan dan meyakinkan calon konsumen mengenai barang dan jasa dengan tujuan untuk memperoleh perhatian, mendidik, mengingatkan dan meyakinkan calon konsumen".

Shimp (2003:111) mengemukakan bahwa promosi mengacu pada setiap insentif yang digunakan oleh produsen untuk memicu transaksi (pedagang besar dan ritel) dan/atau konsumen untukmembeli suatu merek serta mendorong tenaga penjualan untuk secara agresif menjualnya. Dengan kegiatan promosi yang dilakukan, perusahaan akan berusaha untuk membujuk calon pembeli dan langganan untuk melakukan pembelian atas produk yang dipasarkan, dalam hal ini perusahaan melakukan komunikasi dengan konsumen.

Menurut Isnaini (2005:87), promosi adalah kegiatan yang dilakukan perusahaan untuk memberitahukan kebaikan produknya dan membujuk pasar untuk membeli produk tersebut.

\subsubsection{Tujuan Promosi}

Promosi merupakan alat komunikasi dan penyampaian pesan yang dilakukan baik oleh perusahaan maupun perantara dengan tujuan memberikan informasi mengenai produk, harga dan tempat. Informasi itu bersifat memberitahukan, membujuk, mengingatkan kembali kepada konsumen, para perantara atau kombinasi keduanya.

Hal ini sesuai dengan pendapat Buchori ( 2008:85), yang menyatakan bahwa promosi memiliki tujuan memberi informasi, menarik perhatian dan untuk selanjutnya memberi pengaruh terhadap meningkatnya penjualan. Suatu kegiatan promosi jika dilaksanakan dengan baik dapat mempengaruhi konsumen mengenai dimana dan bagaimana konsumen membelanjakan pendapatannya. Promosi berusaha agar demand tidak elastis.

\subsubsection{Bauran Promosi}

Adapun bauran promosi menurut Plilip Kotler yang tercantum dalam buku karangan Saladin (2004 : 172) adalah sebagai berikut : 


\section{Periklanan (Advertising)}

Periklanan adalah semua bentuk penyajian nonpersonal, promosi ide-ide, promosi barang atau jasa yang dilakukan oleh sponsor yang dibayar.

2. Promosi Penjualan (Sales Promotion)

Promosi penjualan adalah variasi insentif jangka pendek untuk merangsang pembelian atau penjualan suatu produk atau jasa.

3. Hubungan masyarakat dan Publisitas (Public Relation and Publicity)

Hubungan masyarakat adalah suatu usaha (variasi) dari rancangan program guna memperbaiki, mempertahankan, atau melindungi perusahaan atau citra produk.

4. Penjualan Persoanal (Personal Selling)

Penjualan pribadi atau tatap muka adalah penyajian lisan dalam suatu pembicaraan dengan satu atau beberapa pembeli potensial dengan tujuan untuk melakukan penjualan.

5. Pemasaran Langsung (Direct Marketing)

Komnikasi secara langsung yang digunakan dari mail, telepon, fax, e-mail, atau internet untuk mendapatkan tanggapan langsung dari konsumen secara jelas.

\subsection{Penjualan}

Penjualan merupakan pembelian sesuatu (barang atau jasa) dari suatu pihak kepada pihak lainnya dengan mendapatkan ganti uang dari pihak tersebut. Penjualan juga merupakan suatu sumber pendapatan perusahaan, semakin besar penjualan maka semakin besar pula pendapatan yang diperoleh perusahaan.

\subsubsection{Pengertian Penjualan}

Aktivitas penjualan merupakan pendapatan utama perusahaan karena jika aktivitas penjualan produk maupun jasa tidak dikelola dengan baik maka secara langsung dapat merugikan perusahaan. Hal ini dapat disebabkan karena sasaran penjualan yang diharapkan tidak tercapai dan pendapatan pun akan berkurang.

Menurut Assauri (2007:121), kegiatan penjualan merupakan kegiatan pelengkap atau suplemen dari pembelian untuk memungkinkan terjadinya transaksi. Jadi kegiatan pembelian dan penjualan merupakan satu kesatuan untuk dapat terlaksananya transfer hak atau transaksi. Oleh karena itu, kegiatan penjualan terdiri dari serangkaian kegiatan yang meliputi penciptaan permintaan (demand), menemukan pembeli, negosiasi harga dan syaratsyarat pembayaran. Dalam hal penjualan ini, penjual harus menentukan kebijaksanaan dan prosedur yang akan diikuti untuk memungkinkan dilaksanakannya rencana penjualan yang telah ditetapkan. Walaupun sering terlihat bahwa usaha atau inisiatif mencari produk datangnya dari pembeli, tetapi penjual haruslah berusaha untuk dapat menemukan pembeli agar transaksi penjualan dapat terlaksana (Assauri, 2007:125).

Pengertian penjualan menurut Simamora(2000:24) menyatakan bahwa; penjualan adalah pendapatan lazim dalam perusahaan dan merupakan jumlah kotor yang dibebankan kepada pelanggan atas barang dan jasa". Sedang Marom (2002:28) menyatakan bahwa : "Penjualan artinya penjualan barang dagangan sebagai usaha pokok perusahaan yang biasanya dilakukan secara teratur". 
Berdasarkan pengertian di atas, maka dapat disimpulkan bahwa penjualan adalah persetujuan kedua belah pihak antara penjual dan pembeli, dimana penjual menawarkan suatu produk dengan harapan pembeli dapat menyerahkan sejumlah uang sebagai alat ukur produk tersebut sebesar harga jual yang telah disepakati.

\section{Metode Penelitian}

\subsection{Lokasi dan Tempat Penelitian}

Adapun yang menjadi lokasi penelitian dilakukan di Jalan Mampang Prapatan No.17 A Mampang, Jakarta Selatan, Indonesia . Sedangkan yang menjadi Objek dalam penelitian ini adalah untuk menganalisis pengaruh Promosi terhadap penjualan pada PT. Hemal Arginusa.

\subsection{Jenis Penelitian}

Penelitian merupakan suatu karya ilmiah yang disusun menggunakan jenis dan strategi tertentu, sehinga dapat dipertanggungjawabkan kebenaran data yang diperoleh. Penelitian dipandang dari aspek-aspek tertentu yang memiliki beberapa jenis dan strategi yang akan digunakan.Terkait dengantulisan ini, jenis penelitian yang digunakan adalah deskriptif dengan pendekatan kuantitatif, merupakan penelitian untuk menguji hipotesis atau menjawab mengenai status terakhir dari subyek penelitian. Penelitian deskriptif kuantitatif, merupakan data yang diperoleh dari sampel populasi penelitian dianalisis sesuai dengan metode statistik yang digunakan. Penelitian deskriptif dalam penelitian ini dimaksudkan untuk mendapatkan gambaran dan keterangan-keterangan mengenai pengaruh promosi terhadap penjualan produk pupuk Hemal Bio oleh PT. PT. Agronusa Jakarta.

\subsection{Variabel Penelitian}

Ada dua variabel dalam penelitian ini yaitu :

Depedent Variable (Y) yaitu penjualan dan independent variabel yang terdiri dari Promosi.

\subsection{Metode Pengumpulan Data}

Pengumpulan data dilakukan dengan cara sampel acak (random sampling) sehingga semua anggota populasi mempunyai hak yang sama untuk menjadi sampel dalam penelitian. Jenis data pada penelitian ini menggunakan data kuantitatif dan kualitatif.

\subsubsection{Populasi dan Sampel Penelitian}

Menurut Sugiyono (2012: 80), "Populasi adalah wilayah generalisasi terdiri atas obyek/subyek yang mempunyai kualitas dan karakteristik tertentu. ditetapkan oleh peneliti untuk dipelajari dan kemudian ditarik kesimpulan”.

Populasi dalam penelitian ini adalah konsumen yang membeli Produk Pupuk Organik di PT. Hemal Agrinusa Jakarta sebanyak 43 orang konsumen. Adapun kriteria sampel ditentukan sebagai berikut : (1) Responden adalah konsumen yang berkunjung atau melakukan pembelian Produk Pupuk Organik di PT. Hemal Agrinusa Jakarta, serta memiliki waktu untuk dimintai informasi; (2) Responden berperan sebagai sumber dalam pengisian kuesioner pengaruh promosi terhadap penjualan Produk Pupuk Organik di PT. Hemal Agrinusa Jakarta;(3) Jumlah Responden diambil dari data sekunderkonsumen di Jakarta yang membeli Produk Pupuk Organik di PT. Hemal Agrinusa Jakarta. 
Sementara itu sampel penelitian menurut Sugiyono (2012: 81) sampel adalah sebagian dari jumlah dan karakteristik yang dimiliki oleh populasi tersebut. Untuk menentukan jumlah sampel dilakukan sebuah sampling. Teknik sampling merupakan teknik pengambilan sampel.

\subsubsection{Teknik Pengambilan Sampel}

Teknik pengambilan sampel yang digunakan adalah non-random sampling, melalui teknik purposive sampling. Ukuran sampel menggunakan rumusSlovin. Sampel dalam penelitian ini adalah jumlah konsumen di Jakarta yang pernah melakukan pembelian Produk Pupuk Organik di PT. Hemal Agrinusa Jakarta pada tahun 2017, menurut informasi yang diterima dari PT. Hemal Agrinusa Jakarta berjumlah 43 konsumen, dengan tingkat kesalahan pengambilan sampel 10\%, menggunakan rumus Slovin sebagai berikut :

$$
\begin{aligned}
& \mathrm{n}= \frac{\mathrm{N}}{1+\mathrm{N}\left(\mathrm{e}^{2}\right)} \\
& \text { Di mana }: \\
& \mathrm{n}=\text { sampel } \\
& \mathrm{N}=\text { populasi } \\
& \mathrm{e}=\text { perkiraan tingkat kesalahan }
\end{aligned}
$$

Berdasarkan rumus diatas, penulis melakukan perhitungan dengan perkiraan tingkat kesalahan 10\% dan diperoleh jumlah responden yang diteliti sebagai berikut :

$$
\begin{aligned}
& \mathrm{n}=\frac{43}{1+43\left(0,1^{2}\right)} \\
& \mathrm{n}=\frac{43}{1+43} \\
& \mathrm{n}=\frac{43}{1,43} \\
& =30,06 \text { responden dibulatkan menjadi } 30 \text { responden }
\end{aligned}
$$

Dari hasil perhitungan dalam tingkat kesalahan 10\% maka yang akan diambil dengan rumus Solvin adalah sebanyak 30 sampel.

\subsection{Metode Analisa Data}

Adapun metode analisis yang digunakan untuk pengujian dan pembuktian hipotesis yaitu,pertama analisis deskriptif. Dalam upaya pemecahan masalah yang dihadapi perusahaan, dalam hal ini PT. Hemal Agrinusa Jakarta, metode analisis yang digunakan pada tahap pertama adalah analisis deskriptifyang menguraikan secara kualitatif relevansi bauran promosi yang digunakan pada PT. Hemal Agrinusa Jakarta dengan penjualan produk pupuk organik. Sedangkan analisis dekriptif adalah metodemetodeyang berkaitan dengan pengumpulan dan penyajian suatu gugus data sehingga memberikan informasi yang berguna. Analisis dekriptif memberikan informasi mengenai sekumpulan datadan mendapatkan gagasan untuk keperluan analisis selanjutnya, jika diperlukan analisis ini meliputipenyusunan ukuran pemusatan, ukuran penyebaran, tabel, diagram, dan grafik. Selain itu, regresisederhana, persamaan analisis 
regresi sederhana digunakan untuk menentukan apakah penjualan secara kuantitatif di PT. Hemal Agrinusa Jakarta dipengaruhi oleh bauran promosi (dalam hal iniperiklanan, penjualan individu, dan promosi penjualan). Regresi yang digunakan adalah regresi sederhana dengan persamaan:

$\mathrm{Y}=\mathrm{a}+\mathrm{bx}$, di mana;

$\mathrm{Y}=$ Penjualan produk pupuk organik

$\mathrm{a}=$ Konstanta

$\mathrm{b}=$ Koefisien regresi

$\mathrm{x}=$ Biaya promosi

Untuk menguji hipotesis digunakan uji korelasi parsial (r) dan determinasi (R) untuk melihatpengaruh dari variabel dependen $(\mathrm{X})$ terhadap variabel independen $(\mathrm{Y})$ dalam model regresi sederhana diatas. Pengujian hipotesis dilanjutkan dengan melakukan uji t yang berfungsimenguji signifikansi dependen yang ada.

\section{HASIL DAN PEMBAHASAN}

\subsection{Hasil Penelitian}

\subsubsection{Karakteristik Responden}

Karakteristik responden merupakan gambaran pemberi informasi atau pembeli produk Pupuk Organik Hemal Bo PT. Hemal Agronusa Jakarta meliputi jenis kelamin, usia, pekerjaan dan jenis pertanian dengan hasil sebagai berikut :

Tabel 1. Identifikasi Responden

\begin{tabular}{|l|c|c|}
\hline URAIAN & FREKUENSI & PROSENTASE \\
\hline JENIS KELAMIN & & \\
A. Laki-laki & 25 & $83,33 \%$ \\
B. Perempuan & 5 & $16,67 \%$ \\
\hline USIA A. 25 Tahun & 2 & \\
B. 25-30 Tahun & 18 & $6,67 \%$ \\
C. $31-35$ Tahun & 3 & $60 \%$ \\
D. 36-40 Tahun & 4 & $10 \%$ \\
E. > 40 Tahun & 3 & $13,33 \%$ \\
\hline Tingkat Pendidikan Terakhir & 5 & $10 \%$ \\
A. SLTA & 20 & $16,67 \%$ \\
B. Diploma & 3 & $66,66 \%$ \\
C. Strata Satu & 2 & $10 \%$ \\
D. Strata Dua & 6,67 \\
Pekerjaan; & \multicolumn{2}{|}{} \\
A. Petani sayuran & 3 & $10 \%$ \\
B. Petani pemula & 1 & $3,33 \%$ \\
C. Petani tanaman keras & 26 & $86,67 \%$ \\
\hline
\end{tabular}

Sumber : Pengolahan data Kuesioner, 2017

Hasil pengolahan data terlihat bahwa pengunjung atau konsumen pupuk organik Hemal adalah sebesar $25(83,33 \%)$ memiliki jenis kelamin laki-laki dan sebesar 5 $(16,67 \%)$ konsumen adalah perempuan. Untuk tingkat usia terlihat bahwa konsumen pembeli produk pupuk organik adalah berusia $25(6,67 \%)$ dan pembeli untuk tingkat 
usia antara 25-30 tahun sebanyak 18 (60\%), tingkat usia antara 31-35 tahun sebanyak $3(10 \%)$, pembeli untuk tingkat usia antara 36-40 tahun sebanyak $4(13,33 \%)$ dan untuk usia di atas 40 tahun sebanyak $3(10 \%)$ dengan demikian terlihat bahwa pembeli pupuk organik Helma Bio secara rata-rata pembeli pada tingkat kedewasaan yang lebih baik. Tingkat pendidikan pembeli produk pupuk Hemal Bio terlihat bahwa pembeli dengan tingkat pendidikan Diploma merupakan tingkat pendidikan tertinggi dengan jumlah $20(66,66 \%)$, untuk pembeli dengan tingkat pendidikan SLTA sebanyak 5 $(16,67 \%)$, untuk pembeli dengan tingkat pendidikan Strata Satu sebanyak 3 (10\%) adapun pembeli dengan tingkat pendidikan strata dua sebanyak $2(6,67 \%)$. Pembeli yang memiliki pekerjaan sebagai petani sayuran sebanyak $3(10 \%)$, sebanyak 1 $(3,33 \%)$ pembeli adalah sebagai petani pemula dan sebanyak $26(86,67 \%)$ adalah petani buah-buahan. Hal ini sesuai dengan data penjualan perusahaan tahun 2017 yang khusus memasarkan pupuk organik Helma Bio.

\subsubsection{Uji Validitas dan Reliabilitas}

Uji validitas dilakukan untuk mengetahui seberapa cermat satu test (alat pengukuran) melakukan fungsi ukurnya, sedangkan uji reliabilitas mengetahui sejauh mana pengukuran ini dapat memberikan hasil yang relatif tidak berbeda bila dilakukan pengukuran kembali terhadap subyek yang sama

Hasil pengolahan data terhadap variable Promosi (X) dimana 14 item berada pada kondisi $r_{h i t u n g}>r_{\text {tabel }}$ dengan demikian ke 14 item dinyatakan valid. Sedangkan satu item yaitu item nomor 13 berada rhitung < rtabel, dinyatakan tidak valid, sehingga tidak dapat diikut sertakan dalam penelitian selanjutnya. Untukuji reliabilitas diperoleh nilai $0.902>0,60$ sehingga variable Promosi dinyatakan memiliki kehandalan. Hasil ini sesuasi dengan pendapat Ghozali $(2008: 135)$ yang menyatakan bahwa variabel dapat dikatakan reliabel jika memberikan nilai cronbach alpha>0,60

Tabel 2. Uji Validitas dan Reliabilitas Variabel Promosi (X)

\begin{tabular}{|c|c|c|c|c|c|}
\hline Item & Jumlah & Total & $\mathrm{r}_{\text {hitung }}$ & $\mathrm{r}_{\text {tabel }}$ & Keterangan \\
\hline 1 & 80 & 1337 & 0,455 & 0.349 & Valid \\
\hline 2 & 73 & 1337 & 0,595 & 0.349 & Valid \\
\hline 3 & 66 & 1337 & 0,579 & 0.349 & Valid \\
\hline 4 & 92 & 1337 & 0,657 & 0.349 & Valid \\
\hline 5 & 103 & 1337 & 0,671 & 0.349 & Valid \\
\hline 6 & 114 & 1337 & 0,717 & 0.349 & Valid \\
\hline 7 & 106 & 1337 & 0,658 & 0.349 & Valid \\
\hline 8 & 99 & 1337 & 0,754 & 0.349 & Valid \\
\hline 9 & 92 & 1337 & 0,519 & 0.349 & Valid \\
\hline 10 & 102 & 1337 & 0,756 & 0.349 & Valid \\
\hline 11 & 81 & 1337 & 0,783 & 0.349 & Valid \\
\hline 12 & 76 & 1337 & 0,414 & 0.349 & Valid \\
\hline 13 & 83 & 1337 & 0,256 & 0.349 & Tidak Valid \\
\hline 14 & 76 & 1337 & 0,647 & 0.349 & Valid \\
\hline 15 & 94 & 1337 & 0,366 & 0.349 & Valid \\
\hline \multicolumn{7}{|c|}{ Alpha =0.902 } \\
\hline
\end{tabular}


Sumber : Pengolahan data SPSS Ver 21.00

Dalam pengujian validitas pada variabel Penjualan (Y) diperoleh hasil 14 item pernyataan berada pada kondisi $r_{\text {hitung }}>r_{\text {tabel }}$ dengan demikian ke 14 item dinyatakan valid dari 15 item yang diujikan. Sementara itu satu item yaitu item nomor 1 berada pada kondisi $r_{\text {hitung }}<r_{\text {tabel }}$ sehinggga dinyatakan tidak valid dan tidak dapat diikut sertakan dalam penelitian selanjutnya. Sementara itu dalam pengujian reliabilitas diperoleh nilai reliabilitas 0.886 dengan demikian nilai reliabilitas $>0,60$ sehingga nilai reliabilitas pada variable Penjualan (Y) dinyatakan memiliki kehandalan.

Tabel 3. Uji Validitas dan Reliabilits Variabel Penjualan (Y)

\begin{tabular}{|c|c|c|c|c|c|}
\hline Item & Jumlah & Total & $\mathrm{r}_{\text {hitung }}$ & $\mathrm{r}_{\text {tabel }}$ & Keterangan \\
\hline 1 & 108 & 1492 & 0,273 & 0.349 & Tidak Valid \\
\hline 2 & 112 & 1492 & 0,515 & 0.349 & Valid \\
\hline 3 & 108 & 1492 & 0,596 & 0.349 & Valid \\
\hline 4 & 107 & 1492 & 0,605 & 0.349 & Valid \\
\hline 5 & 95 & 1492 & 0,611 & 0.349 & Valid \\
\hline 6 & 97 & 1492 & 0,519 & 0.349 & Valid \\
\hline 7 & 103 & 1492 & 0,523 & 0.349 & Valid \\
\hline 8 & 96 & 1492 & 0,369 & 0.349 & Valid \\
\hline 9 & 90 & 1492 & 0,588 & 0.349 & Valid \\
\hline 10 & 98 & 1492 & 0,455 & 0.349 & Valid \\
\hline 11 & 90 & 1492 & 0,627 & 0.349 & Valid \\
\hline 12 & 96 & 1492 & 0,666 & 0.349 & Valid \\
\hline 13 & 92 & 1492 & 0,717 & 0.349 & Valid \\
\hline 14 & 99 & 1492 & 0,626 & 0.349 & Valid \\
\hline 15 & 101 & 1492 & 0,707 & 0.349 & Valid \\
\hline \multicolumn{7}{|c|}{ Alpha = 0.886 } \\
\hline
\end{tabular}

Sumber : Pengolahan data SPSS Versi 21.00

\subsubsection{Uji Normalitas Data}

Uji normalitas dilakukan untuk mengetahui apakah data yang diambil dalam penelitian berasal dari populasi yang berdistribusi normal atau tidak. Model regresi yang baik adalah yang datanya berdistribusi normal atau mendekati normal. Jika data tidak berada di sekitar wilayah garis diagonal dan tidak mengikuti garis diagonal atau tidak mengikuti pola sebaran distribusi normal, maka akan diperoleh taksiran yang bias. Pengujian normalitas dalam penelitian ini digunakan Uji Kolmogorove-Smirnov dengan menggunakan spss versi 21 dan diperoleh hasil sebagai berikut:

Tabel 4. Hasil Uji Normalitas Data dengan Uji Kolmogorove - Smirnov 


\begin{tabular}{|c|c|c|}
\hline & & $\begin{array}{c}\text { Unstandardized } \\
\text { Residual }\end{array}$ \\
\hline $\mathrm{N}$ & & 30 \\
\hline Normal Parameters ${ }^{a, b}$ & Mean & ,0000000 \\
\hline & Absolute & 101 \\
\hline Most Extreme Differences & Positive & 101 \\
\hline & Negative &,- 074 \\
\hline Kolmogorov-Smirnov Z & &, 552 \\
\hline Asymp. Sig. (2-tailed) & & ,921 \\
\hline
\end{tabular}

a. Test distribution is Normal.

b. Calculated from data.

Dari tabel 1 diatas dapat diketahui bahwa besarnya nilai Asymp sig (2-tailed) sebesar 0,921>0,050, hal ini sesuai dengan ketentuan yang telah ditetapkan maka dapat disimpulkan bahwa data tersebut berdistribusi normal dan dapat digunakan dalam penelitian.

\subsubsection{Uji Linieritas}

Uji linearitas adalah pengujian yang bertujuan untuk mengetahui apakah regresi bersifat linier atau tidak. Uji linieritas dalam penelitian ini menggunakan tabel ANOVA variabel $\mathrm{X}$ dan Y dari nilai signifikan. Apabila nilai signifikan tabel ANOVA $<0,05$ maka dapat disimpulkan bahwa hubungan bersifat linier. Uji linier dalam penelitian ini juga menggunakan spss 21 dengan hasil pengujian sebgai berikut:

Tabel 5. Hasil Uji Linieritas dengan Uji ANOVA

\begin{tabular}{|rl|r|r|r|r|r|}
\hline Model & & Sum of Squares & df & Mean Square & F & Sig. \\
\hline \multirow{2}{*}{1} & Regression & 908,712 & 1 & 908,712 & 29,837 &, $000^{\mathrm{b}}$ \\
& Residual & 852,755 & 28 & 30,456 & & \\
& Total & 1761,467 & 29 & & & \\
\hline
\end{tabular}

a. Dependent Variable: Penjualan

b. Predictors: (Constant), Promosi

Berdasarkan gambar tersebut dapat dilihat bahwa nilai signifikan tabel ANOVA sebesar 0,000 . Artinya nilai signifikan kurang dari $0,05(0,000<0,05)$ yang berarti bahwa hubungan bersifat linier. Hal ini menunjukan bahwa Promosi (X) berpola linier terhadap Penjualan (Y).

\subsubsection{Analisis Regresi Sederhana}

Pengaruh Promosi (X) terhadap Penjualan (Y) dapat dilihat dengan menggunakan analisis regresi linier sederhana dengan persamaan; $\mathrm{Y}=\mathrm{a}+\mathrm{bX}$

Di mana:

$$
\begin{aligned}
\mathrm{Y} & =\text { Penjualan } \\
\mathrm{a} & =\text { Konstanta } \\
\mathrm{b}_{1}, \mathrm{~b}_{2} & =\text { koefisien regresi }
\end{aligned}
$$




\section{$\mathrm{X}=$ Promosi}

Hasil pengolahan analisis regresi sederhana dengan menggunakan software Spss 21 adalah sebagai berikut:

Tabel 6. Hasil Analisis Regresi Sederhana

\begin{tabular}{|c|c|c|c|c|c|c|}
\hline \multirow{2}{*}{\multicolumn{2}{|c|}{ Model }} & \multicolumn{2}{|c|}{ Unstandardized Coefficients } & Standardized & \multirow[t]{2}{*}{$\mathrm{t}$} & \multirow[t]{2}{*}{ Sig. } \\
\hline & & $\mathrm{B}$ & Std. Error & Beta & & \\
\hline \multirow{2}{*}{1} & (Constant) & 16,407 & 5,534 & & 2,965 & ,006 \\
\hline & Promosi & ,711 & ,130 & ,718 & 5,462 &, 000 \\
\hline
\end{tabular}

a. Dependent Variable: Penjualan

Berdasarkan perhitungan spss tersebut diperoleh persamaan regresi linier sederhana adalah; Penjualan $(Y)=16.407+0.711 X$

Dari persamaan regresi linier sederhana diatas diperoleh nilai konstanta sebesar 16.407. Artinya, jika variabel Penjualan (Y) tidak dipengaruhi oleh Promosi(X) bernilai nol, maka besarnya rata-rata Penjualan akan bernilai 16.407. Nilai koefisien regresi pada variabel-variabel bebasnya menggambarkan apabila diperkirakan variabel bebasnya naik sebesar satu point dan nilai variabel bebas lainnya diperkirakan konstan atau sama dengan nol, maka nilai variabel terikat diperkirakan bisa naik atau bisa turun sesuai dengan tanda koefisien regresi variabel bebasnya. Koefisien regresi untuk variabel bebas $\mathrm{X}$ (Promosi) bernilai positif, menunjukkan adanya hubungan yang searah antara Promosi (X) dengan Penjualan (Y). Koefisien regresi variabel X sebesar 0.711 mengandung arti untuk setiap pertambahan Promosi (X) sebesar satu satuan akan menyebabkan meningkatnya Penjualan (Y) sebesar 0.711 .

\subsubsection{Analisis Korelasi}

Analisis korelasi digunakan untuk mengetahui hubungan variabel independent (Promosi, X) di PT. Hemal Agronusa, Jakarta. Melalui analisis korelasi ini akan dicaripengaruh variabel independent terhadap variabel Penjualan (Y).

Tabel 7 .Pedoman Interpretasi Koefisien Korelasi

\begin{tabular}{|c|c|c|}
\hline & Interval Kelas & Kategori \\
\hline 1 & $0,000-0,199$ & Sangat Lemah \\
\hline 2 & $0,200-0,399$ & Lemah \\
\hline 3 & $0,400-0,599$ & Cukup Kuat \\
\hline 4 & $0,600-0,799$ & Kuat \\
\hline 5 & $0,800-1,000$ & Sangat Kuat \\
\hline
\end{tabular}

Sumber: Sugiuyono (2010:183)

Analisis ini dilakukan dengan menggunakan software spss 21.00 dan diperoleh hasil analisis korelasi antara variabel independent (Promosi) dengan variabel dependent (Penjualan) sebagi berikut;

Tabel 8. Korelasi Promosi (X) dengan Penjualan (Y)

\begin{tabular}{|c|c|c|c|c|}
\hline Model & $\mathrm{R}$ & $\mathrm{R}$ Square & $\begin{array}{c}\text { Adjusted } \mathrm{R} \\
\text { Square }\end{array}$ & $\begin{array}{c}\text { Std. Error of the } \\
\text { Estimate }\end{array}$ \\
\hline
\end{tabular}




\begin{tabular}{l|r|r|r|r|}
\hline 1 &, $718^{\mathrm{a}}$ &, 516 &, 499 & 5,51865 \\
\hline
\end{tabular}

Berdasarkan output tersebut dapat dilihat bahwa koefisien korelasi antara variabel independent dan dependent sebesar 0,718. Koefisien korelasi bertanda positif artinya korelasi yang terjadi antara variabel Promosi (X) dengan Penjualan (Y) adalah searah, dimana semakin besar kedua variabel independent maka akan diikuti oleh semakin besarnya variabel dependent. Nilai 0,718 menunjukan korelasi yang terjadi antara variabel independent (Promosi) dengan variabel dependent (Penjualan) berada dalam kategori hubungan yang kuat $(0,600-0,799)$.

\subsubsection{Koefisien Determinasi}

Koefisien determinasi pada intinya mengukur seberapa jasuh kemampuan model dalam menerangkan variasi variabel. Koefisien determinasi ini digunakan karena dapat menjelaskan kebaikan dari model regresi dalam variabel dependen. Semakin tinggi nilai koefisien determinasi maka akan semakin baik pula kemampuan variabel independen dalam menjelaskan variabel dependen.Nilai oefisien determinasi adalah antara nol dan satu. Nilai $\mathrm{R}^{2}$ yang kecil berarti kemampuan variabel-variabel independen dalam menjelaskan variasi dependen amat terbatas. Nilai yang mendekati satu berarti variabel-variabel independen memberikan hampir semua informasi yang dibutuhkan untuk memprediksi variabel-vavriabel dependen.

Dari hasil perhitungan koefisien determinasi Nilai (R-square) diperoleh hasil sebesar $\mathrm{R}^{2}=51,6 \%$ atau $\left(0,718^{2} \times 100 \%\right)=51,6 \%$ yang berarti bahwa kontribusi Promosi terhadap Penjualan sebesar 51,6\%. Hal inimenunjukkan bahwa semakin tinggi Promosi (X) makasemakin tinggi pula Penjualan, sebaliknya semakin rendah Promosi (X) kerjanyamaka semakin rendah pula Penjualannya. Sedangkan signifikansi pengaruh Promosi (X) terhadap Penjualan (Y) ditunjukkan oleh Nilai t-hitung sebesar 5,462. Jika dibandingkan dengan nilai t-tabel sebesar 2,048 maka t-hitung yang diperoleh jauh lebih besar dari nilai t-tabel. Sehingga Ho ditolak. Dengan demikian dapat disimpulkan bahwa variabel Promosi (X) berpengaruh secara signifikan terhadap Penjualan (Y).

\section{PEMBAHASAN}

Salah satu faktor untuk meningkatkan penualan adalah promosi. Promosi dapat dikatakan sebagai kegiatan pemasaran untuk meningkatkan penjualan produknya. Dengan demikian, promosiperusahaan yang meningkat akan berdampak positif pada peningkatan penjualan perusahaan. Dari hasil temuan mengenai Pengaruh Promosi terhadap Penjualan Produk Pupuk Hemal Bio oleh PT. Hemal Agronusa Jakarta. Hal ini dapat dibuktikan dengan hasil regresi variabel Promosi memiliki nilai 0,711 maka Penjualan akan meningkat sebesar 0,711 . Hal ini dipertegas oleh pengujian dengan nilai thitung 5,462 dan ttabel (95\%:30-2) sebesar 2.048, dengan tingkat signifikansi atau Pvalue $=0,000$ artinya lebih kecil dari tingkat signifikansi $\alpha=0,05$. Dari hasil tersebut maka kriteria pengujiannya yaitu thitung $>$ ttabel dan Pvalue $<\alpha$ artinya $\mathrm{H}_{0}$ ditolak dan $\mathrm{H}_{1}$ diterima. Kesimpulannya Promosi berpengaruh positif dan signifikan terhadap Penjualan Produk Pupuk Hemal Bio oleh PT. Hemal Agronusa, Jakarta. 
Hasil ini menunjukan bahwa Promosi sangat mempengaruhi Penualan dengan melihat promosi yang merupakan alat berkomunikasi untuk membujuk, menginformasikan suatu produk yang menyebabkan orang tersebut melakukan tindakan. Seseorang sering melakukan tindakan untuk suatu hal mencapai tujuan. Promosi mempersoalkan bagaimana caranya mendorong gairah konsumen atau calon pembeli, agar mereka mau membeli produk untuk mewujudkan tujuan perusahaan.

\section{KESIMPULAN}

Simpulan dari hasil penelitiandan pembahasan Pengaruh Promosi terhadap Penjualan Produk Pupuk Organik Hemal Bio, serta dengan menggunakan landasanteori yang berhubungan dengan penelitian, simpulan penelitian adalah sebagai berikut. Pertama, data yang diolah dari 30 responden menunjukkan produk pupuk Hemal Biomengalami kenaikan volume penjualan. Kedua, untuk saat ini kebijakan promosi yang dilakukan oleh perusahaan PT. Hemal Agronusa Jakart adalah periklanan (advertising), penjualan individu (personal selling), dan promosi penjualan (sales promotion). Ketiga, berdasarkan hasil perhitungan analisisregresi terlihat adanya hubungan yang kuat dari nilai korelasi (R) antara promosi yangdilakukan dengan peningkatan penjualan produk. Hal ini didukung pula oleh hasil uji-t yangmembuktikan bahwa hipotesis yang diajukan dalam penelitian ini dapat diterima. 


\section{DAFTAR PUSTAKA}

Alma, Buchari. 2006. Pemasaran dan Pemasaran Jasa, Bandung: Alfabeta

Assauri, Sofjan, 2007. Manajemen Pemasaran, Jakarta: Rajawali Pers

Dinas Pertanian dan Tanaman Pangan Provinsi Bali. 2012. Laporan Subsidi Pupuk Organik Provinsi Bali.

Isnaini, M. 2006. Pertanian Organik, Untuk Keuntungan Ekonomi dan Kelestarian. Bumi. Yogyakarta: Kreasi Wacana.

Kotler, Philip. 2002. Manajemen Pemasaran. Edisi Milenium. Jakarta: Penerbit Prenhallindo

Leiwakabessy, F.M. dan Sutandi, A. 2004. Diktat kuliah Pupuk dan Pemupukan. Jurusan tanah, Fakultas Pertanian, Bogor: Institut Pertanian Bogor

Chairol Marom, 2002, Sistem Akuntansi Perusahaan Dagang, Jakarta: PT. Grasindo

Saladin dan Yevis Marty Oesman, 2002, Intisari Pemasaran dan Unsur - Unsur. Pemasaran, Cetakan Kedua, Bandung : Penerbit Linda Karya

Shimp,Terence, A.,2003. Periklanan Promosi \& Aspek Tambahan Komunikasi. Pemasaran.Terpadu, Jilid I ( edisi 5), Jakarta: Erlangga

Simamora Henry. 2000. Manajemen Pemasaran Internasional. Jilid 1 Edisi Cetak. 1, Jakarta: Salemba Empat

Sugiyono. 2012. Metode Penelitian Kuantitatif Kualitatif dan R\&D. Bandung: Alfabeta

Winarno, F.G. 2002. Pangan Organik dan Pengembangannya di Indonesia, Harian Kompas 4 November 2002, Jakarta. 